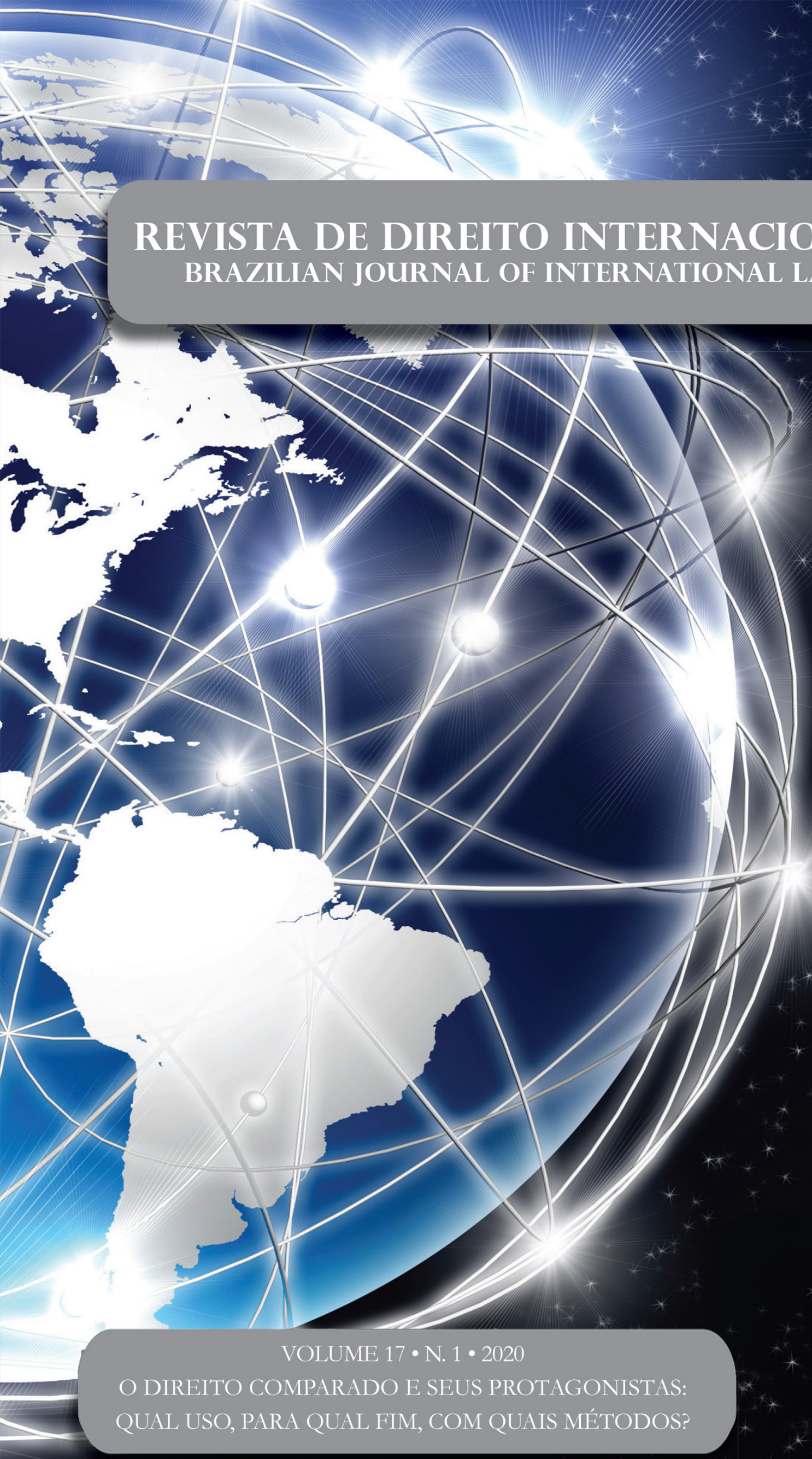

Suprema Imprecisão: a

metodologia em Direito

Constitucional Comparado e as deficiências em seu uso pelo Supremo Tribunal Federal

Supreme Imprecision: the methodology in Constitucional Comparative Law and the deficiencies in its use by the Brazilian Supreme Court

Alonso Freire Hugo Sauaia 
Parte I - O Direito comparado e seus Protagonistas: QuAL uso, PARA QUAL FIM, COM QUAIS MÉTODOS? .....................................................................1

EDITORIAL ............................................................................................................... 3

"Tudo o que precisamos fazer é ter certeza de que continuaremos conversando".............................. 3

Gustavo Cerqueira e Patrícia Perrone Campos Mello

Direito comparado E METOdologia $\quad$................................................... 6

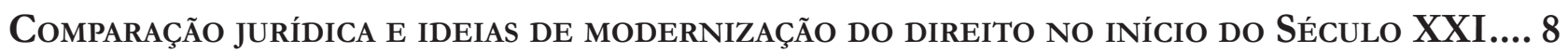
Gustavo Cerqueira

O DIREITO COMPARADO: ESFORÇO DE RESGATE HISTORIOGRÁFICO E DE PROBLEMAS METODOLÓGI$\cos$

Arnaldo Sampaio de Moraes Godoy e Gustavo Fereira Ribeiro

Direito Comparado e Política: Reflexões Necessárias .42

Raphael Carvalho de Vasconcelos e Deo Campos Dutra

Direito comparado no Brasil

L'originalité du Droit Brésilien et le Droit Comparé .57

Arnoldo Wald

LEI DA BOA RAZÃo E COMPARATISMO JURÍDICO NA DOUTRINA CIVILISTA BRASILEIRA DE 1850 A 1880

Alan Wruck Garcia Rangel

O STF EM REDE? QUANTO, COMO, COM QUE ENGAJAMENTO ARGUMENTATIVO O STF USA PRECEDENTES ESTRANGEIROS EM SUAS DECISÕES?

Patrícia Perrone Campos Mello e Felipe Meneses Graça 
Suprema Imprecisão: a metodologia em Direito Constitucional Comparado E as deficiênCias Em Seu uso pelo Supremo Tribunal Federal

Alonso Freire e Hugo Sauaia

Direitos comparados

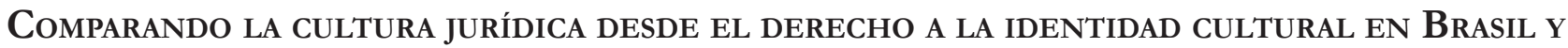

CHILE 145 Juan Jorge Faundes e Fabian Le Bonniec

O Divino e o Racional no Direito: notas para um diálogo entre sistemas jurídicos 181 Salem Hikmat Nasser e José Garcez Ghirardi

Regulação do discurso de Ódio: análise comparada em países do Sul Global 196 Jane Reis Gonçalves Pereira, Renan Medeiros de Oliveira e Carolina Saud Coutinho

Parte II - Outros temas

LA OTRA CARA DE LA MONEDA: PROTECCIÓN CONSTITUCIONAL DE LA EMPRESA, EL EMPRENDIMIENTO Y LA LIBRE COMPETENCIA EN CHILE y COLOMBiA

Juan Pablo Díaz Fuenzalida e Juan Sebastián Villamil Rodríguez

The European Court of Human Rights Decision on there 'Burqa Ban'and the CritiCal analysis of the Pragmatic experimental logic 258 Flavianne Fernanda Bitencourt Nóbrega e George Browne Rego

Direitos humanos das deslocadas ambientais e os impactos da Usina de Belo Monte: da EXPLORAÇÃO AMAZÔNICA À SUBJUGAÇÃO FEMININA

Thais Silveira Pertille e Letícia Albuquerque

Solução de Controvérsias em Acordos de Investimento: as experiênCias do CPTPP, CETA E DOS ACFIs

Fábio Morosini, Vivian Daniele Rocha Gabriel e Anastacia Costa

50 anos dos “direitos da Criança” na Convenção Americana de Direitos Humanos: a HISTÓRIA DO ARTIGO 19 311

Sven Peterke e Paloma Leite Diniz Farias 
EMPRESAS E DIREITOS HUMANOS: COMPARTILHANDO VALOR E RESPONSABILIDADES .325 Melina Girardi Fachin

CONTEMPORARY RESPONSES TO BUSINESSES' NEGATIVE HUMAN RIGHTS IMPACT 341 Andres Felipe Lopez

Human Right to LABOR PROTECTION IN UKRAINE: CURRENT SITUATION AND THE PROSPECTS OF IMPLEMENTATION OF INTERNATIONAL RULES 363 Nina Daraganova

International Regulation and Global Governance: The EU influential Method IN TIMES OF NORMATIVITY CHANGE 373 Gabriela Hühne Porto, Paula Wojcikiewicz Almeida e Juliana Maia F. A. Netto

Tecnologias digitais e o comércio de bens E SERviços na OMC/Digital. 391 Umberto Celli Junior

Los fuertes hacen lo QUe PUeden: exponiendo los límites de la Corte Penal InternaCIONAL .406

Cristián D. González-Ruiz e Víctor M. Mijares

Human Rights, Humanitarian Law and State Power 418 Renata Nagamine e João Roriz

Regional integration in the South Pacific: Challenges for Public governance .433 Joanna Siekiera

Parte III - Resenhas 443

RESENHA DA OBRA

“Democracia e policentrismo do poder", de Murilo Gaspardo 445 Angela Limongi Alvarenga Alves 


\title{
Suprema Imprecisão: a metodologia em Direito Constitucional Comparado e as deficiências em seu uso pelo Supremo Tribunal Federal*
}

\author{
Supreme Imprecision: the methodology \\ in Constitucional Comparative Law and \\ the deficiencies in its use by the Brazilian \\ Supreme Court
}

\author{
Alonso Freire** \\ Hugo Sauaia***
}

\section{Resumo}

O presente estudo inicia com um questionamento fundamental feito pelo juiz Antonin Scalia, da Suprema Corte norte-americana, sobre a pertinência da utilização de precedentes oriundos de outras Cortes Constitucionais ou Supremas Cortes nas decisões particulares de um país. Desta discussão, pretendeu-se reconstruir com o recurso à dogmática, as etapas e métodos utilizáveis pelo Direito Constitucional Comparado, desde abordagens tradicionais a abordagens críticas. Em seguida, realizou-se pesquisa empírica na ferramenta de busca por jurisprudência disponível no sítio eletrônico do Supremo Tribunal Federal, por aquelas decisões que indicassem a referência ao uso de "direito comparado", o que resultou em 41 (quarenta e uma) indicações a Informativos, que são depositários de decisões selecionadas como relevantes na história da Corte, e que foram analisados, um a um, a fim de identificar a forma como ela vem utilizando tal recurso, com seus limites, erros e acertos. O resultado é uma breve, porém, profunda análise quantitativa e qualitativa sobre a imprecisão no uso de referidos precedentes da experiência estrangeira em um conciso e elucidativo panorama que abrange décadas de decisões do Tribunal.

Palavras-chave: Direito Constitucional Comparado. Supremo Tribunal Federal. Metodologias.

* Recebido em 04/10/2019

Aprovado em 16/05/2020

** Doutor em Direito Público pela Universidade do Estado do Rio de Janeiro. Mestre em Direito Constitucional pela Universidade Federal de Minas Gerais. Professor Adjunto da Universidade Federal do Maranhão. Assessor de Ministro no Supremo Tribunal Federal. Email: alonsoreis@gmail.com

*** Doutorando em Direito do Estado pela USP. Mestre em Direito Constitucional pelo IDP. Professor da Universidade CEUMA. Advogado. Email: hugosauaiaadvocacia@gmail.com

\section{Abstract}

This study begins with a fundamental question proposed by the former Justice of the Supreme Court of the United States Antonin Scalia concerning the relevance of using precedents from other Constitutional or Supreme Courts in a country's particular legal decisions. From his argumentation it was intended to rebuild with the help from theoretical studies, the stages and methods applied by Comparative Constitutional Law, since traditional approaches to critical ones. It was diagnosed then, the epistemological fea- 
tures that are possible and acceptable for a scientifical usage of this legal branch. Following, empirical research took place with the help of the Brazilian Supreme Court search mechanism for precedents withing the Court's data base, searching for mentions of "comparative law", which resulted in 41 (forty one) indications of Informatives, which are sources for selected relevant cases from the Court's history, which were analysed, one by one, in order to identify the ways foreign precedents have been used: limits, mistakes and right choices. The result is a brief but deep - quantitative and also qualitative - analysis on the imprecision of these preceden's use in a concise but yet elucidative overview which encompasses decades of the tribunal's decisions.

Keywords: Comparative Constitutional Law. Brazilian Supreme Court. Methodologies.

\section{Introdução}

A hipótese que se pretende examinar neste artigo é a de que o Supremo Tribunal Federal não tem, em sua experiência decisória, uma metodologia ou abordagem bem definida de utilização e aplicação da experiência estrangeira em Direito Constitucional Comparado. Utilizaria sem critérios e sem a incursão necessária, decisões aleatórias - com forte destaque para a jurisprudência da Suprema Corte norte-americana, seja em razão do acesso mais fácil aos seus precedentes, seja pelo compreensível idioma inglês - sem, todavia, amparar, mesmo esses precedentes, na literatura jurídica do país de origem e no contexto político e histórico nacional de sua prolação.

Quanto à metodologia a ser utilizada, ela se dividirá em duas partes. De início, no tocante à sistematização dos parâmetros adequados para as incursões no material de outras Cortes em matéria constitucional, a metodologia será eminentemente dogmática, realizada por meio de pesquisa bibliográfica e estudo analítico da literatura disponível e atual sobre o tema, em sintonia com as posições doutrinárias mais sólidas possíveis, dentro de uma perspectiva lógica e fundamentada.

Em uma segunda parcela do trabalho, decisões do STF serão objeto de análise qualitativa e qualitativa sob o crivo desses pressupostos. Partir-se-á da análise de to- dos os Informativos ${ }^{1}$ de Jurisprudência produzidos pela própria Corte, acessíveis por meio de sua base online a partir da busca pela expressão direito comparado. Destacam-se, por intermédio da utilização deste mecanismo, sem restrições a anos, relatores ou órgãos, 41 (quarenta e um). Informativos ${ }^{2}$, que foram lidos e examinados, para permitir o exame e posteriores conclusões. Tais Informativos atendem a uma grande diversidade de conteúdos, e são destacados pela própria assessoria administrativa como casos relevantes no histórico decisório do Tribunal, permitindo, assim, a atenção a amostra significativa de julgados, disponíveis pelo meio mais utilizado para acesso por pesquisadores e profissionais da área jurídica em geral.

Ao final, pretende-se diagnosticar criticamente, a partir da análise quantitativa e qualitativa dos precedentes do STF, em cotejo com a construção teórica já exposta, como esta Corte vem guiando suas decisões por tais amostras de Direito estrangeiro, e se o acolhimento de tais posições atende a alguma das modalidades científicas de pesquisa antecipadas. Ao final trar-se-á à luz uma realidade que hoje permanece apagada, uma visão mais ou menos panorâmica, sobre o uso pelo STF da jurisprudência em Direito Constitucional Comparado e suas particularidades.

\section{Da pesquisa em Direito Constitucional Comparado: relevância e metodologia.}

Em janeiro de 1998, diante de uma realidade distinta, e em certa medida incompreensível para os mais jovens, se podia fumar a bordo de aeronaves comerciais. Abid Hanson, um médico egípcio, asmático, e alérgico à fumaça de cigarros, embarcou em uma aeronave da Olympic Airways, na qual viajaria do Cairo para Nova Ior-

Os Informativos consistem em precedentes da própria Corte, selecionados por sua assessoria técnica, e que pretendem veicular, uniformemente, decisões relevantes, que inovam ou mantém orientações já consolidadas. Não sendo possível a análise de todo o acervo do STF, por razões óbvias de extensão, os Informativos parecem delimitar, com razoável relevância e alcance, aquelas decisões representativas do modus operandi do Tribunal, e que permitam a verificação de como tem decidido em matéria de utilização de Direito Comparado Constitucional.

2 Pesquisa realizada no site do STF (Disponível em: http://www. stf.jus.br/portal/jurisprudencia/listarConsolidada.asp. Acesso em: 28 ago. 2019). 
que, uma viagem longa. Tendo solicitado assentos para não-fumantes, fora surpreendido com a sua colocação a apenas três fileiras de fumantes. Mesmo diante de suas súplicas e de sua esposa, os comissários de bordo não consentiram em providenciar a sua mudança de lugar, tanto logo no embarque, quanto minutos depois, ao sofrer os primeiros sinais da forte reação alérgica que o levaria à morte.

A esposa de Abid Hanson, Rubina Hanson, processou, então, a companhia aérea, buscando responsabilizá-la. Ela obteve decisões favoráveis em primeiro e segundo graus. A Olympic Airways recorreu à Suprema Corte norte-americana, que manteve as decisões, entendendo correta a aplicação, pelas instâncias inferiores, da Convenção de Varsóvia, considerando acidente indenizável a negativa de auxílio ao passageiro.

$\mathrm{Na}$ Suprema Corte, o juiz Antonin Scalia protagonizaria, em seu voto vencido neste julgamento, verdadeira ironia, ao afirmar que a repentina insularidade da Corte - por adotar compreensão distinta de outros Tribunais estrangeiros - seria assustadora, já que em anos recentes teria ela "[...] examinado cuidadosamente a lei prevalente em outras nações a fim de determinar o significado da Constituição Americana, com a qual tais nações não contribuíram, e cujas Cortes não têm a tarefa de fazer cumprir"3. A observação seria apenas uma das várias objeções levantadas pelo juiz Scalia, quanto ao uso, sem metodologia aparente, da jurisprudência constitucional de outros países, e a forma como serviria de fundamento - ou subterfúgio - para a compreensão do direito nacional.

Em outro momento, discutiria a Suprema Corte a existência de um direito individual de processar o Estado por violações a Direitos Humanos. Humberto Alvares-Machain havia sido sequestrado pela DE $A-D r u g$ Enforcement Administration, agência federal de combate ao tráfico de drogas, e levado aos Estados Unidos, para que fosse acusado criminalmente. Uma vez absolvido, processou a União em razão dos atos promovidos para a sua captura ilegal no estrangeiro e deslocamento ao país. O juiz Scalia seria ainda mais ácido agora em 2004, em sua opinião concorrente, ao afirmar, que “[...] os próprios Constituintes, estou convicto, se assustariam

UNITED STATES. SUPREME COURT OF THE UNITED STATES. Olympic Airways v. Husain, 540 U.S. 644 (2004). Disponível em: https://supreme.justia.com/cases/federal/us/540/644/. Acesso em: 27 set. 2019. pela proposição que, por exemplo, a adoção democrática pelo povo americano da pena de morte, poderia ser reconhecida nula em razão da visão de censura de estrangeiros". Aduziu, ainda, que a compreensão de que o uso da convicção jurídica estrangeira, "[...] sobre qualquer assunto, poderia ser usada para controlar o tratamento soberano de seus próprios cidadãos, dentro seu próprio território, é uma invenção de professores internacionalistas do Século XX e advogados de direitos humanos". 4

Scalia admitiria, posteriormente, o uso da experiência judicial de outros países, mas unicamente como fonte de exemplos e experiências que possam ser usados para modificar as leis, ou mesmo, por meio do procedimento formal adequado, alterar a própria Constituição. Quanto às possíveis consultas, pelas Cortes norte-americanas, permaneceria coerente com suas opiniões e rigor, para afirmar que seriam legítimas tão somente quando estivessem sob análise a aplicação de Tratados ou Convenções Internacionais. Suas objeções assim, seriam tanto metodológicas, quanto relativas à legitimidade constitucional e democrática da utilização das soluções de Direito comparado:

Se existia algum pensamento absolutamente
estranho aos constituintes do nosso país, certamente
seria a noção de que nós Americanos deveríamos
ser governados da mesma forma que Europeus
o são... Que razão existe para se acreditar que
outras disposições de um país estrangeiro sejam
tão obviamente adequadas à moral e às maneiras de
nosso povo que possam ser judicialmente impostos
por meio de decisões judiciais? Seria mesmo uma
função apropriada para a juízes quais são e quais
não são?

As opiniões de Scalia ilustram muito bem as dificuldades enfrentadas para o uso adequado do direito constitucional em sua perspectiva comparada. O objetivo deste artigo não é, particularmente, o de adentrar aos argumentos relativos à legitimidade do uso da experiência estrangeira por Cortes Supremas ou Constitucionais, em especial no cenário brasileiro. Parte-se, todavia, de pressupostos já expostos alhures. Primeiro, de uma constatação prática, a de que o uso do direito estrangei-

4 UNITED STATES. THE UNITED STATES COURT OF APPEALS FOR THE NINTH CIRCUIT. Sosa v. Alvarez-Machain, 542 U.S. 692. 2004. Disponível em: http://cdn.loc.gov/service/ll/ usrep/usrep542/usrep542692/usrep542692.pdf. Acesso em: 28 ag. 2019.

5 SCALIA, Antonin. Keynote address: Foreign Legal Authority in the Federal Courts. Proceedings to the Annual Meeting, Cambridge, v. 98, march/april, p. 305-310, 2004. 
ro na interpretação constitucional por tribunais nacionais em suas decisões é hoje cada vez mais comum ao redor do mundo, tem sido observada em vários países, como, por exemplo, África do Sul, Alemanha, Argentina, Austrália, Brasil, Canadá, Espanha, Estados Unidos, França, Holanda, Hungria, Índia, Inglaterra, Israel, Itália e Rússia. Daí a necessidade de estudá-lo como fenômeno jurídico. ${ }^{6}$

À guisa de justificativa normativa abrangente ${ }^{7}$, se reconhece que dois fundamentos seriam suficientes para admitir a utilização de precedentes estrangeiros. $\mathrm{O}$ primeiro deles é um argumento muito utilizado pelos entusiastas da invocação judicial voluntária do direito estrangeiro: a possibilidade de se aprender com outras jurisdições, uma vez que cada qual é, sem sombra de dúvidas, amálgama e miríade de casos e experiências que frequentemente se repetem e se sobrepõem. O segundo, por sua vez, é a aplicação em nível transnacional de uma reconhecida máxima: o dever de tratar casos iguais de forma igual, corolário lógico e pressuposto real da noção de isonomia como igual valorização da vida humana. Não há Constituição democrática que negue, parece fácil afirmar, mesmo que em extensões divergentes, a igualdade como máxima, e, da mesma forma, não parece haver sistema jurídico e constitucional, não-autocrático, que negue a experiência humana, representada também em jurisprudência, como fonte de aprendizado e amadurecimento:

Um cientista não pensa em prosseguir em uma
investigação sobre a gravidade ou energia sem
referência ao trabalho já realizado pela comunidade
científica. Ele se baseia em e começa a partir de
resultados estabelecidos e verificados. E o mesmo
é verdade para o direito. Nós não tentamos resolver
[nossos] problemas como se o mundo nunca
tivesse lidado com eles. Damos atenção para o que
outros juristas fizeram ao enfrentarem o problema.
Tratamo-lo como um problema a ser resolvido
dando atenção às opiniões estabelecidas pela ciência
jurídica - a experiência que compartilham muitos
sistemas jurídicos em combatê-lo, esclarecê-lo,
analisá-lo, de resolver reivindicações rivais e direitos

FREIRE, Alonso. Interpretação constitucional comparativa: aproximação crítica e arcabouço metodológico. Publicum, Rio de Janeiro, v. 2, n.1, 2016. Disponível em: http://www.e-publicacoes.uerj. br/. Acesso em: 20 jun. 2017.

Destaca-se, desde logo, que o presente trabalho parece corroborar, no tocante à relevância e possível utilização adequada do Direito Constitucional Comparado, com outros trabalhados anteriormente publicados neste periódico. Cf. HORBACH, Carlos Bastide. O direito comparado no STF: internacionalização da jurisdição constitucional brasileira. Revista de Direito Internacional. V.12, n.2, 2015. em colisão, princípios e valores que se juntam em questões desse tipo. ${ }^{8}$

Acredita-se, todavia, que a utilização de metodologia adequada, ${ }^{9}$ própria ao Direito Constitucional Comparado, seja mecanismo que permitirá a resposta a um dos questionamento mais interessantes e relevantes para a discussão da legitimidade da utilização de tal recurso argumentativo, problema maior no qual está de certa forma imerso este estudo, mais que transborda seus limites: o de como usar casos semelhantes, de sistemas semelhantes, sem o risco de incorrer-se, por ausência de critérios reais de escolha e seleção, em mera abordagem pautada em verdadeiros argumentos de autoridade, em mera referência a sistemas de países supostamente em estágio mais avançado de desenvolvimento institucional.

A utilização aleatória incorre, assim, em duplo erro, pois além de pautar-se em suposta superioridade intelectual ou experimental - denotando o que Mangabeira Unger chama de imitação e mistura de constituições adotadas nos países do Attântico Norte, um traço de subserviência intelectual e mentalidade colonialista ${ }^{10}$ não serve de critério científico, corroborando possíveis falácias argumentativas e solipsismos, pela via da seleção de casos particularmente melhores para a representação da opinião pessoal do julgador.

S WALDRON, Jeremy. Partly laws common to all mankind: foreign law in american courts. New Haven: Yale University Press, 2012. p. 103. 9 "Segundo Samuel, para escapar dessa análise incompleta é fundamental pensar o direito comparado dentro de uma perspectiva epistemológica investigativa, driblando a perspectivada autoridade normativa que é marca dos trabalhos de pesquisa que analisam o direito num panorama interno. Mas porque a metodologia, e consequentemente o método, esse temido companheiro dos pesquisadores, é tão importante para o direito comparado? Essa é uma incômoda pergunta, que poucos pesquisadores do direito gostam de fazer. A complexa relação entre a pesquisa científica jurídica e os métodos utilizados por ela é bem conhecida da academia. Alguns autores alegam, inclusive, que a pesquisa jurídica é lamentavelmente marcada pela ausência do rigor do método, que, ao contrário, contribui de maneira importante em outras searas para uma melhor produção de conhecimento (LARENZ, 2014, p. 3). Essa realidade, contudo, não pode ser expandida para todas as disciplinas jurídicas. $\mathrm{O}$ direito comparado vem há anos debatendo insistentemente questões relativas ao método. A comparação jurídica vem se firmando como uma ação profícua para esse tipo de questão. Esse debate se torna ainda mais importante na medida em que hoje comparar sistemas jurídicos distintos se tornou quase que compulsório para a pesquisa jurídica (VAN HOECKE, 2014, p. 1).” DUTRA, Deo Campos. Métodos em Direito Comparado. Revista da Faculdade de Direito - UFPR, Curitiba, v. 61, n. 3, p. 189-212, set./dez. 2016.

10 UNGER, Roberto Mangabeira. A constituição do experimentalismo democrático. Revista de Direito Administrativo, Rio de Janeiro, v. 257, p. 57-72, maio-ago. 2011. 
Uma abordagem analítica e construída dentro do rigor metodológico adequado e antecipável permitirá, ao menos, a localização do problema e a compreensão de quando, como e em que grau usar precedentes estrangeiros, e poderá servir de referencial teórico-prático para o cotejo da experiência da própria atuação de Cortes específicas, como o Supremo Tribunal Federal (STF).

Ao se consultar a literatura mais tradicional, descobre-se que a pesquisa comparativa consiste em três fases distintas: fase identificativa, fase descritiva e fase de explicação ${ }^{11}$. Primeiro, todo pesquisador deve decidir sobre qual questão ele deseja pesquisar e escolher em qual ou em quais sistemas jurídicos ele deseja realizar sua pesquisa. Segundo, o pesquisador precisa descrever o objeto de sua pesquisa nos sistemas jurídicos escolhidos. Terceiro, ele precisa tentar explicar as semelhanças e diferenças encontradas no que diz respeito ao seu objeto de pesquisa. Uma quarta etapa tem sido incluída por alguns autores recentes. Nela, o pesquisador deve avaliar seus achados empíricos.

Com dito resumidamente, na primeira etapa duas decisões precisam ser tomadas. Primeiro, o que pesquisar. Mas antes de se avançar é preciso esclarecer que existem dois níveis distintos de comparação: macro-comparação e micro-comparação ${ }^{12}$. Tradicionalmente, o nível macro tem sido relacionado à comparação entre sistemas jurídicos de diferentes nações (ex. os direitos alemão, francês, inglês etc.). Nesse nível, é o próprio sistema jurídico como um todo - direitos infranconstitucional e constitucional - que figura como objeto da pesquisa. Mas, no mundo, o número de sistemas jurídicos é quase idêntico ao número de países. No entanto, com alguns critérios, tem sido possível agrupar diferentes sistemas jurídicos em tradições jurídicas (ex. civil law, commom law, direito talmúdico, direito islâmico etc.), que são formas mais genéricas ${ }^{13}$ que também podem ser ob-

11 CRUZ, Peter de. Comparative Law in a Changing World. 2nd edn. London: Routledge Cavendish, 1999. p. 233-239; ÖRÜCÜ, Esin. Methodological Aspects of Comparative Law. European Journal of Law Reform, [S. 1.], v. 8, p. 29-42, 2006; SIEMS, Mathias. Comparative Law. Cambridge: Cambridge University Press, 2014. p. 13 e ss; DANNEMANN, Gerhard. Comparative Law: Study of Similarities or Differences? In: REIMANN, Mathias; ZIMMERMANN, Reinhard (eds.). The Oxford Handbook of Comparative Law. Oxford: Oxford University Press, 2006. p. 406-419.

12 ÖRÜCÜ, Esin. The Enigma of Comparative Law: Variations on a Theme for Twenty-First Century. Leiden: Martius Nijhoff, 2004. p. 40.

13 Sobre a superação da ideia de famílias jurídicas pela noção de tradições jurídicas, confira GLENN, H. Patrick. Comparative Legal Families and Comparative Legal Traditions. In: REIMANN, Mathi- jetos de comparação em nível macro ${ }^{14}$.

Por outro lado, o nível micro relaciona-se tradicionalmente a elementos que compõem os sistemas jurídicos ou que são encontrados em tradições jurídicas. Nesse nível, os pesquisadores podem decidir pesquisar sobre os mais variados temas e objetos jurídicos. Por exemplo, normas (ex. liberdade, igualdade etc.), conceitos jurídicos (razoabilidade, eficiência etc.), instituições jurídicas (tribunais, parlamentos etc.), institutos jurídicos (amparos, veto etc.), métodos de interpretação (gramatical, sistemático etc.), decisões etc.

No nível micro, um problema surge quando nos países ou tradições escolhidos não existe o objeto da investigação. Seria o caso por exemplo de se desejar pesquisar referendos e plebiscitos em um sistema no qual esses institutos não existem. Quanto a esse problema, muitos comparatistas afirmam que o erro está na abordagem focada no objeto a ser investigado. Eles sustentam que a abordagem deve ser baseada na solução dada pelo sistema a determinado problema. Em outras palavras, e considerando o exemplo, eles querem dizer que os pesquisadores na verdade devem pesquisar quais soluções os sistemas escolhidos oferecem para a participação popular. Portanto, essa abordagem funcionalista compara as possíveis soluções oferecidas pelos sistemas escolhidos para questões específicas e reais.

Quando o pesquisador resolve realizar micro-comparações, uma segunda decisão precisa ser tomada. Essa decisão diz respeito à questão sobre quais sistemas jurídicos ou quais tradições jurídicas ele deve incluir em sua pesquisa. Pelo menos duas questões práticas devem ser consideradas nessa escolha. A primeira diz respeito à quantidade de sistemas a serem incluídos. Obviamente, sua pesquisa pode ser feita em mais de um sistema e em mais de uma tradição ou mesmo em sistemas jurídicos de uma mesma tradição (ex. direito alemão e francês, ambos da common law). É claro que, além do idioma, a escolha dos países depende do tópico a ser analisado. Para o iniciante, é aconselhável a inclusão de três países. Explica-se: não se compara um país com ele próprio, exceto na dimensão do tempo; a redução a dois países pode enfatizar excessivamente o contraste ou as seme-

as; ZIMMERMANN, Reinhard (eds.). The Oxford Handbook of Comparative Law. Oxford: Oxford University Press, 2006. p. 421-440.

14 Confira por todos, GLENN, H. Patrick. Legal Traditions of the World: Sustainable Diversity in Law. Oxford: Oxford University Press, 2014. 
lhanças; com três países, é mais fácil estabelecer o que determina tanto as semelhanças e diferenças, isolando explicações possíveis. Tradicionalistas aconselham a escolha de sistemas nem muitos estranhos nem tão familiares, especialmente em primeiras pesquisas comparadas. Assim, não é aconselhável que um pesquisador brasileiro familiarizado com este sistema envolva em sua pesquisa os sistemas talmúdicos e islâmico, exceto se ele tiver familiaridade com eles e não tenha dificuldades com os idiomas envolvidos.

É claro que a escolha dos sistemas jurídicos pode influenciar o resultado da pesquisa, e isso não é negativo. Por essa razão, o pesquisador precisa, antes de escolher os sistemas, tentar antecipar que tipos de diferenças e semelhanças são possíveis identificar entre os sistemas que ele pode escolher. Essa antecipação é possível, já que o pesquisador já tem em mente certo número de ideias e elementos informativos que o levam a escolher o tópico de pesquisa e os sistemas.

A segunda questão diz respeito às fontes de pesquisa. Tradicionalmente, na pesquisa jurídica, dois tipos de fontes são reconhecidos: as primárias e as secundárias. É recomendado que uma primeira pesquisa se limite às fontes primárias (legislação, resoluções, decisões judiciais, decisões administrativas etc.). Quanto às decisões judiciais e administrativas, por exemplo, uma limitação adicional pode ser feita: o pesquisador pode restringir suas pesquisas a um determinado tribunal ou a outros órgãos, como conselhos administrativos, por exemplo. Essa limitação evidentemente deve considerar a relação entre competência do tribunal ou órgão em questão e o tópico da pesquisa. A consulta a fontes secundárias (artigos, livros especializados etc.), a princípio, também deve obedecer à exigência do idioma original. Quanto a essas últimas fontes, é recomendado que sejam de autoria de estudiosos nacionais reconhecidos e com inquestionável familiaridade com o tópico da pesquisa, a tradição ou o sistema sob análise.

Essa etapa consiste em uma descrição de normas, conceitos, doutrinas, decisões, instituições e outros objetos de pesquisa. Não há dúvidas de que existem diferentes perspectivas para a descrição de um objeto. Com respeito ao direito e seus elementos não poderia ser diferente. Assim, um comparatista pode tentar descrever uma lei estrangeira a partir de seu próprio ponto de vista, como um observador. Ele também pode se esforçar e tentar descrevê-la a partir do ponto de vista do sistema jurídico (ou tradição legal) ao qual ela pertence, como um participante, o que lhe exige maior esforço. Por último, o comparatista pode tentar descrever a mesma lei de um ponto de vista neutro, o que é controverso e cuja possibilidade hoje é bastante questionada. Em geral, tradicionalistas se opõem à primeira opção e se mostram divididos quanto às duas últimas ${ }^{15}$. É que, quanto a primeira, eles afirmam que não devemos deixar a pesquisa ser influenciada pelas compreensões que temos sobre o nosso próprio sistema. Por exemplo, um jurista familiarizado com o sistema jurídico norte-americano, ao estudar o sistema jurídico da Inglaterra, não pode concluir que neste último não há precedentes judiciais simplesmente baseando-se no que a cultura jurídica norte-americana compreende por precedentes judiciais. Nos dois países e em outros mais, o significado de precedente judicial pode variar. Mas isso não significa que esse instituto jurídico não existe em alguns lugares apenas por não corresponder àquilo que o sistema do próprio pesquisador reconhece como precedente judicial.

No que diz respeito às duas últimas opções acima mencionadas - descrição do ponto de vista interno e neutralidade descritiva -, alguns estudiosos insistem que o comparatista deve se esforçar em apresentar o tópico de sua pesquisa da mesma maneira que um jurista nativo o faria se lhe fosse solicitado. Outros acreditam que o comparatista pode, sim, realizar uma descrição neutra, sobretudo se ele adotar a abordagem funcionalista, sobre qual ainda falaremos.

Ainda sobre a etapa da descrição, comparatistas discutem sobre se seria aconselhável ou não a tradução de termos jurídicos estrangeiros. De fato, há riscos, já que qualquer forma de tradução pode deixar escapar importantes aspectos e detalhes do que é traduzido, provocando distorções conceituais. No direito não é diferente. Indiscutivelmente, muitos termos jurídicos possuem significados enraizados na cultural jurídica. Com efeito, embora eles possam ter correspondentes no idioma

\footnotetext{
SIEMS, Mathias. Comparative Law. Cambridge: Cambridge University Press, 2014. p. 16-17.
} 
do pesquisador, seu real significado e sua real aplicação podem ser bastante diferentes. Imagine-se um pesquisador de sistemas jurídicos cujo o idioma seja o inglês, este pode muito facilmente ter problemas com o termo precedent, que para muitos parece ser de simples tradução, mas cujo significado real varia enormemente de um sistema para outro, acarretando dificuldades para o pesquisador. Foi o que ocorreu na prática com um pesquisador que, diante das múltiplas concepções de precedentes com as quais se deparou em sua pesquisa, julgou apropriado dar o seguinte título à sua tese: Raciocinando com Decisões Anteriores ao invés de ... com Precedentes ${ }^{16}$.

Sobre a tradução de termos, existem duas posições. Adeptos da primeira sustentam que a tradução é necessária tendo em vista que os leitores não são obrigados a conhecer os termos originais encontrados pelo pesquisador. A tradução dos termos facilitaria sua compreensão ampliando o público leitor. $\mathrm{Na}$ visão oposta estão aqueles que sustentam que a tradução pode acarretar compressões equivocadas, seja pela simplificação excessiva, seja pelo seu exagerado distanciamento.

Há uma alternativa para esse dilema. Primeiro, o comparatista pode tentar aplicar linguística jurídica comparativa ${ }^{17}$. Esta via é difícil. Segundo, pode o comparatista elaborar uma tradução ao termo ou expressão mantendo a versão original entre colchetes, quando aparecerem pela primeira vez no artigo. Essa última opção é mais comum e menos complexa. Ela pode ser acompanhada de uma explicação contextualizada do termo em nota de rodapé. Mas há termos cujos significados não geram maiores problemas de tradução devido à sua proximidade linguística e sua correspondência comparativa. Com isso, eles podem ser facilmente vertidos ao idioma do texto ou do público alvo.

Outro aspecto, ainda quanto a essa segunda etapa, envolve a questão a propósito do que considerar como direito nos sistemas estudados. Embora a discussão teórica em torno da questão "o que é o Direito?" seja importante e fundamental, comparatistas - especialmente os

\footnotetext{
16 O pesquisador é Jan Komárek. Sobre essa e outras dificuldades metodológicas em sua pesquisa, confira KOMÁREK, Jan. Reasoning with Previous Decisions. In: ADAMS, Maurice. (ed.). Practice and Theory in Comparative Law. Cambridge: Cambridge University Press, 2012. p. 49-73.

17 Confira a respeito, JANSEN, Nils. Comparative Law and Comparative Knowledge. In: REIMANN, Mathias; ZIMMERMANN, Reinhard (eds.). The Oxford Handbook of Comparative Law. Oxford: Oxford University Press, 2006. p. 320-325.
}

tradicionalistas - aconselham o pesquisador iniciante a não se engajar nessa discussão e a considerar o direito apenas como o sistema jurídico em questão o considera. Isso, evidentemente, exige, em alguns casos, uma análise preliminar sobre quais são as fontes jurídicas reconhecidas pelo sistema sob análise. A questão pode se tornar mais difícil quando o sistema jurídico não menciona expressamente quais são suas fontes ou quando as remete a outra disciplina ${ }^{18}$.

Alguns tradicionalistas ${ }^{19}$ consideram que aspectos sociológicos, econômicos, históricos e culturais locais precisam ser considerados pelo pesquisador já na etapa da descrição. Esses aspectos serviriam para esclarecer, por exemplo, porque determinadas fontes são reconhecidas pelos sistemas analisados. Mas essa sugestão é controversa. É que esses aspectos podem comprometer a própria descrição. O ponto positivo é que a sua inclusão tornaria a pesquisa ainda mais interdisciplinar, agregando informações extrajurídicas à comparação logo nessa etapa. Parece, contudo, ser mais prudente deixar esses aspectos para a próxima etapa.

É intuitivo que a tarefa de comparar envolve, em alguma medida, a exploração de semelhanças e diferenças. De fato, isso forma parte da própria noção de direito comparado, já que não haveria sentido em se realizar uma comparação sem a identificação de semelhanças e diferenças.

Nessa terceira etapa, deve ser feita, em primeiro lugar, a identificação das diferenças e semelhanças entre os objetos de pesquisa. Aqui, dois passos são geralmente adotados pelos tradicionalistas. O primeiro deles é identificar as semelhanças e as diferenças. Essa identificação consiste numa abordagem de duas dimensões, uma formal e outra funcional ${ }^{20}$. A dimensão formal é voltada à análise do conteúdo das regras jurídicas comparadas. A segunda dimensão, por sua vez, é direcionada à verificação da aplicabilidade concreta dessas normas.

Após identificadas as semelhanças e diferenças é preciso explicá-las. As explicações podem ser buscadas em outros campos do conhecimento. Sem dúvidas, fatores econômicos, históricos, culturais, étnicos, filosó-

\footnotetext{
18 Por exemplo, a Constituição do Egito aprovada em 2012, mas já revogada, estabelecia em seu art. $2^{\circ}$ que "[o] islã é a religião do Estado... Os princípios da Sharia islâmica são a principal fonte da legislação".

19 Op. Cit.

20 SIEMS, Mathias. Comparative Law. Cambridge: Cambridge University Press, 2014. p. 20.
} 
ficos, econômicos, políticos, religiosos e até geográficos podem fornecer boas razões para a existência de diferenças e semelhanças encontradas ${ }^{21}$. Evidentemente, o pesquisador precisa se considerar habilitado para analisar e correlacionar esses fatores às semelhanças e diferenças encontradas. Portanto, nessa etapa é exigido do pesquisador um maior esforço, sobretudo se ele não tiver familiaridade com outras áreas do conhecimento, como História, Política, Religião, Filosofia, Econômica, Antropologia etc. Evidentemente, é um risco para o pesquisador do Direito usar essas áreas com as lentes jurídicas.

Embora alguns autores expressem dúvidas sobre o papel crítico do pesquisador na comparação, podemos dizer que uma análise comparativa serve pelo menos para que ele possa fazer uma avaliação crítica do seu próprio sistema jurídico. Portanto, conhecendo outros sistemas, o pesquisador poderá avaliar e sugerir reformas ao seu próprio sistema jurídico a fim torná-lo mais justo ou eficaz. Como afirmam ainda Rafael Ferreira e Celine Anadon ${ }^{22}$ :

As novas demandas dessa sociedade não podem
eficazmente serem enfrentadas por uma única
ordem jurídica estatal no âmbito do respectivo
território ou mesmo pela dependência de uma
racionalidade autoritária e impositiva que não se
estrutura sob premissas partilháveis.

Uma das questões que mais tem atraído o interesse de comparatistas contemporâneos é o impacto de ideias jurídicas estrangeiras em sistemas jurídicos domésti$\cos ^{23}$. Mensurar com que frequência Cortes citam outras Cortes, sejam estas nacionais ou internacionais, tem sido objeto de muitos trabalhos importantes que dão corpo ao que pode ser chamado de comparatismo judicial. É evidente que o direito comparado quantitativo vai além do simples levantamento numérico. O parágrafo a seguir ilustra esse tipo de pesquisa.

\footnotetext{
21 Aqui, um ponto bastante interessante diz respeito à questão sobre se as semelhanças são contingentes ou genealógicas, o que leva ao tema hoje bastante discutido dos transplantes legais.

22 FERREIRA, Rafael F.; ANADON, Celine B. O diálogo hermenêutico e a pergunta adequada à aplicação dos tratados internacionais de direitos humanos no Brasil: caminhos para o processo de internacionalização da constituição. Revista de Direito Internacional. V.12, n.2, 2015.

23 GRAZIADEI, Michele. Comparative Law as the Study of Transplants and Receptions. In: REIMAN, Mathias; ZIMMERMANN, Reinhard (eds.). The Oxford Handbook of Comparative Law. Oxford: Oxford University Press, 2006. p. 441-512.
}

Em uma pesquisa bastante abrangente ${ }^{24}$, Martin Gelter e Mathias Siems examinaram o uso de decisões estrangeiras nas Cortes não constitucionais da Alemanha, Áustria, Bélgica, Espanha, França, Holanda, Inglaterra, Irlanda, Itália e Suíça. Eles analisaram mais de 600.000 decisões proferidas entre 2000 e 2007 e encontraram um total de 1.430 citações de precedentes estrangeiros. Como algumas dessas Cortes têm competências diversas, eles limitaram a pesquisa a casos envolvendo apenas direito civil e direito penal. A partir desse levantamento, eles realizaram várias análises e concluíram, por exemplo, que algumas Cortes têm certas preferencias: a Áustria citou 459 vezes a Alemanha e a Irlanda, 456 vezes a Inglaterra. Isso significa que um total de 915 - o equivalente a $64 \%$ - das citações foram de apenas dois países: Alemanha e Inglaterra. Os autores notaram também, por exemplo, que a Irlanda citou a Inglaterra em 98\% dos casos; a Áustria, a Alemanha, em 94\% do casos; a Espanha, a Alemanha, em 88\% do casos; a Bélgica, a França, em 70\%; a Suíça, a Alemanha, em 70\% dos casos; e a Itália, a França em 67\% dos casos. Eles especularam que talvez a linguagem e a similaridade da cultura jurídica sejam os fatores determinantes desses achados. Outras conclusões foram tiradas a partir da aplicação da técnica econométrica de regressão binomial negativa. Um número significativo de variáveis independentes foi examinado como potencialmente explicativas das diferenças encontradas ${ }^{25}$.

Evidentemente, esse tipo de pesquisa é do interesse de constitucionalistas. Sem dúvidas, a despeito de alguns desafios distintos, a metodologia quantitativa tem muito a oferecer ao estudo comparativo constitucional. Essa metodologia "[...] permite o comparatista resolver uma série de novas questões, assim como gerar novos insights em debates já existentes" ${ }^{\text {"2 }}$. Por exemplo, nos últimos anos tem-se constatado que muitas Cortes constitucionais e supremas têm feito uso de empréstimos constitucionais e internacionais ${ }^{27}$. Esses empréstimos podem

\footnotetext{
24 GELTER, Martin; SIEMS, Mathias. Citations to Foreign Courts - Illegitimate and Superfluos, or Unavoidable? Evidence from Europe. The American Journal of Comparative Law, Oxford, v. 62, n. 35, p. 35-86, 2014.

25 As mensurações de influência de trabalhos acadêmicos e de leis estrangeiras e internacionais em decisões judiciais também são possíveis.

26 MEUWESE, Anne; VERSTEEG, Mila. Quantitative Methods for Comparative Constitutional Law. In: ADAMS, Maurice; BOMHOFF, Jacco (eds.). Practice and Theory in Comparative Law. Cambridge: Cambridge University Press, 2012. p. 231.

27 Confira, por exemplo, CHOUDHRY, Sujit. The Migration of
} 
ser de normas estrangeiras e internacionais, bem como de decisões e precedentes de tribunais nacionais e internacionais. $\mathrm{O}$ fenômeno tem sido estudado a partir de diversas perspectivas, inclusive - talvez, necessariamente - quantitativa ${ }^{28}$. Mas “[...] os comparatistas também podem usar dados quantitativos para mapear o universo constitucional e identificar diferenças e semelhanças através de diferentes sistemas jurídicos, simplesmente sumarizando e contando dados quantitativos" ${ }^{29}$.

Em resumo, como afirma Mathias Siems, "[...] o direito comparado numérico pode contribuir para muitos temas centrais do direito comparado, tais como o direito judicial comparativo, transplantes legais, famílias jurídicas e comparações como uma base para se fazer recomendações políticas" ${ }^{\prime 3}$. Evidentemente, os números não afastam completamente as dúvidas: “[...] nós não podemos ter a certeza sobre o que esses números realmente nos dizem; portanto, o desafio é a intepretação das possíveis causas e consequências" ${ }^{\prime 31}$. Portanto, é recomendável a combinação de abordagens qualitativas e quantitativas, já que os números precisam ser interpretados.

\section{Análise empírica do comportamento do Supremo Tribunal Federal quando da utilização de Direito Comparado}

Ao longo das duas últimas décadas, o STF tem decidido, como nunca, questões constitucionais muito difíceis e importantes. Quanto aos direitos fundamentais, em particular, o Supremo Tribunal Federal tem decidido casos verdadeiramente históricos, com grande repercussão na sociedade. Nos últimos dez anos, o Tribunal dis-

Constitutional Ideas. New York: Cambridge University Press, 2006; HALMAI, Gábor. The Use of Foreign Law in Constitutional Interpretation. In: ROSENFELD, Michel; SAJÓ, András (eds.). The Oxford Handbook of Constitutional Law. Oxford: Oxford University Press, 2012. p. 1328-1348.

28 GROPPI, Tania; PONTHOREAU, Marie-Claire. The Use of Foreign Precedents by Constitutional Judges. Oxford: Hart Publishing, 2014.

29 MEUWESE, Anne; VERSTEEG, Mila. Quantitative Methods for Comparative Constitutional Law. In: ADAMS, Maurice; BOMHOFF, Jacco (eds.). Practice and Theory in Comparative Law. Cambridge: Cambridge University Press, 2012. p. 232.

30 SIEMS, Mathias. Comparative Law. Cambridge: Cambridge University Press, 2014. p. 186.

31 SIEMS, Mathias. Comparative Law. Cambridge: Cambridge University Press, 2014. p. 186. cutiu questões moralmente complexas como, por exemplo, as relacionadas ao racismo e ao anti-semitismo ${ }^{32}$, ao reconhecimento jurídico das uniões estáveis entre parceiros do mesmo sexo ${ }^{33}$, ao direito à interrupção da gestação de fetos inviáveis ${ }^{34}$, à prisão de depositário infiel ${ }^{35}$, ao uso de algemas ${ }^{36}$, à progressão de regime prisional ${ }^{37}$, à liberdade de expressão e manifestações favoráveis à descriminalização de drogas ${ }^{38}$, à eficácia horizontal dos direitos fundamentais ${ }^{39}$, ao mandado de injunção ${ }^{40}$, ao sistema de cotas para ingresso no ensino superior em

BRASIL. Supremo Tribunal Federal. Habeas Corpus 82.424 - Rio Grande do Sul. Relator Min. Moreira Alves, redator para Acórdão Min. Maurício Corrêa. Brasília, DF, 2003. Disponível em: https:// stf.jusbrasil.com.br/jurisprudencia/770347/habeas-corpus-hc82424-rs. Acesso em: 27 set. 2019.

33 BRASIL. Supremo Tribunal Federal. Arguição de Descumprimento de Preceito Fundamental 132 - Rio de Janeiro. Relator Min. Ayres Britto. Brasília, DF, 2011. Disponível em: http://redir.stf.jus.br/paginadorpub/paginador.jsp?docTP $=\mathrm{AC} \& d o c I D=628633$. Acesso em: 27 set. 2019.

34 BRASIL. Supremo Tribunal Federal. Arguição de Descumprimento de Preceito Fundamental 54 - Distrito Federal. Relator Min. Marco Aurélio. Brasília, DF, 2012. Disponível em: http://redir.stf.jus.br/paginadorpub/paginador.jsp?docTP $=$ TP\&docID $=3707334$. Acesso em: 27 set. 2019.

35 BRASIL. Supremo Tribunal Federal. Recurso Extraordinário 349.703 - Rio Grande do Sul. Relator Min. Carlos Britto. Brasília, DF, 2008. Disponível em: http://redir.stf.jus.br/paginadorpub/paginador.jsp?docTP=AC\&docID=595406. Acesso em: 27 set. 2019.

36 BRASIL. Supremo Tribunal Federal. Habeas Corpus 91.952-9 São Paulo. Relator Min. Marco Aurélio. Brasília, DF, 2008. Súmula Vinculante $\mathrm{n}^{\circ}$ 11. Disponível em: http://redir.stf.jus.br/paginadorpub/paginador.jsp?docTP $=\mathrm{AC} \& \operatorname{docID}=570157$. Acesso em: 27 set. 2019

37 BRASIL. Supremo Tribunal Federal. Habeas Corpus 82.959-7 - São Paulo. Relator Min. Marco Aurélio. Brasília, DF, 2006. Disponível em: http://www.stf.jus.br/noticias/imprensa/VotoGilmarHC82959.pdf. Acesso em: 27 set. 2019.

38 BRASIL. Supremo Tribunal Federal. Arguição de Descumprimento de Preceito Fundamental 187 - Distrito Federal. Relator Min. Celso de Melo. Brasília, DF, 2011. Disponível em: http://www.stf.jus.br/arquivo/cms/noticiaNoticiaStf/anexo/ADPF187merito.pdf. Acesso em: 27 set. 2019.

39 BRASIL. Supremo Tribunal Federal. Recurso Extraordinário 201.819-8 - Rio de Janeiro. Relatora Min. Ellen Gracie. Brasília, DF, 2005. Disponível em: http://redir.stf.jus.br/paginadorpub/paginador.jsp?docTP=AC\&docID=388784. Acesso em: 27 set. 2019.

40 BRASIL. Supremo Tribunal Federal. Mandado de Injunção 670 Espirito Santo. Relator Min. Gilmar Mendes. Brasília, DF, 2007. Disponível em: https://stf.jusbrasil.com.br/jurisprudencia/2926661/ mandado-de-injuncao-mi-670-es. Acesso em: 27 set. 2019; BRASIL. Supremo Tribunal Federal. Mandado de Injunção 708 - Distrito Federal. Relator Min. Gilmar Mendes. Brasília, DF, 2007. Disponível em: https://stf.jusbrasil.com.br/jurisprudencia/14725991/mandadode-injuncao-mi-708-df. Acesso em: 27 set. 2019; BRASIL. Supremo Tribunal Federal. Mandado de Injunção 712-8 - Pará. Relator Min. Eros Grau. Brasília, DF, 2007. Disponível em: http://www.stf.jus.br/imprensa/PDF/mi712.pdf. Acesso em: 27 set. 2019. 
instituições públicas ${ }^{41}$ e ao uso de células embrionárias em pesquisas científicas ${ }^{42}$. Não menos importantes foram, por exemplo, as decisões relativas à fidelidade partidária $^{43}$, à constitucionalidade do Conselho Nacional de Justiça $(\mathrm{CNJ})^{44}$, ao direito de minorias de requerer a instalação de comissões parlamentares de inquérito ${ }^{45}$, à demarcação de terras indígenas ${ }^{46}$, à constitucionalidade da lei de imprensa ${ }^{47}$, à constitucionalidade do Estatuto do Desarmamento ${ }^{48}$, à questão da chamada Lei da Ficha Limpa $a^{49}$, à proibição de nepotismo na administração pú-

41 BRASIL. Supremo Tribunal Federal. Arguição de Descumprimento de Preceito Fundamental 189 - São Paulo. Relator Min. Ricardo Lewandowski. Brasília, DF, 2012. Disponível em: https://stf.jusbrasil.com. $\mathrm{br} /$ jurisprudencia/21812440/arguicao-de-descumprimento-de-preceito-fundamental-adpf-189-sp-stf. Acesso em: 27 set. 2019.

42 BRASIL. Supremo Tribunal Federal. Ação Direta de Inconstitucionalidade 3.510 - Distrito Federal. Relator Min. Ayres de Britto. Brasília, DF, 2008. Disponível em: http://redir.stf.jus.br/paginadorpub/ paginador.jsp?doc $\mathrm{TP}=\mathrm{AC} \& \operatorname{doc} \mathrm{ID}=611723$. Acesso em: 27 set. 2019.

43 BRASIL. Supremo Tribunal Federal. Mandado de Segurança 26.602 - Distrito Federal. Relator Min. Eros Grau. Brasília, DF, 2007. Disponível em: https://www.jusbrasil.com.br/topicos/27706686/ stf-mandado-de-seguranca-ms-26602-df. Acesso em: 27 set. 2019.

44 BRASIL. Supremo Tribunal Federal. Ação Direta de Inconstitucionalidade 3.367 - Distrito Federal. Relator Min. Cezar Peluso. Brasília, DF, 2005. Disponível em: https://stf.jusbrasil.com.br/jurisprudencia/765314/acao-direta-de-inconstitucionalidade-adi-3367-df. Acesso em: 27 set. 2019.

45 BRASIL. Supremo Tribunal Federal. Mandado de Segurança 24.831-9 - Distrito Federal. Relator Min. Celso de Mello. Brasília, DF, 2005. Disponível em: http://www2.stf.jus.br/portalStfInternacional/cms/verConteudo.php?sigla=portalStfJurisprudencia_pt_ br\&idConteudo $=185070 \&$ modo $=\mathrm{cms}$. Acesso em: 27 set. 2019 .

46 BRASIL. Supremo Tribunal Federal. Petição 3.388 - Roraima. Relator Min. Ayres Britto. Brasília, DF, 2009. Disponível em: http://redir.stf.jus.br/paginadorpub/paginador. jsp?docTP=TP\&docID=5214423. Acesso em: 27 set. 2019.

${ }_{47}$ BRASIL. Supremo Tribunal Federal. Arguição de Descumprimento de Preceito Fundamental 130 - Distrito Federal. Relator Min. Ayres Britto. Brasília, DF, 2009. Disponível em: http://redir.stf.jus.br/paginadorpub/paginador.jsp?doc $T P=A C \& d o c I D=605411$. Acesso em: 27 set. 2019.

48 BRASIL. Supremo Tribunal Federal. Ação Direta de Inconstitucionalidade 3.112-1 - Distrito Federal. Relator Min. Ricardo Lewandowski. Brasília, DF, 2007. Disponível em: http://www.stf.jus.br/imprensa/ pdf/adi3112.pdf. Acesso em: 27 set. 2019.

49 BRASIL. Supremo Tribunal Federal. Ação Direta de Inconstitucionalidade 4.578 - Distrito Federal. Relator Min. Luiz Fux. Brasília, DF, 2012. Disponível em: http://redir.stf.jus.br/paginadorpub/paginador.jsp?doc'TP=TP\&docID=2257978. Acesso em: 27 set. 2019; BRASIL. Supremo Tribunal Federal. Ação Declaratória de Constitucionalidade 29 - Distrito Federal. Relator Min. Luiz Fux. Brasília, DF, 2012. Disponível em: http://redir.stf.jus.br/paginadorpub/paginador. jsp?docTP $=$ TP\&docID $=2243342$. Acesso em: 27 set. 2019; BRASIL. Supremo Tribunal Federal. Ação Declaratória de Constitucionalidade 30 - Distrito Federal. Relator Min. Luiz Fux. Brasília, DF, 2012. Disponível em: http://redir.stf.jus.br/paginadorpub/paginador. jsp?docTP=TP\&docID=2243411. Acesso em: 27 set. 2019. blica $^{50}$, à constitucionalidade da Lei de Anistia ${ }^{51}$, entre outras.

Em todos esses casos houve invocação de decisões e legislações estrangeiras e internacionais em quantidade surpreendente. É bem verdade que muitas Cortes constitucionais recorrem a essas fontes, mas, pelo menos em uma análise preliminar, é razoável concluir que o Supremo Tribunal Federal o faz em maior frequência, volume e intensidade, e sem adotar qualquer metodologia. Além disso, e o que é muito incomum em Cortes de outros países, há, no STF, ampla e deliberada invocação de doutrinas estrangeiras, sobretudo as de origem norte-americana e alemã ${ }^{52}$.

No tocante à jurisprudência do STF, é perceptível a tendência de invocação dessas fontes não apenas como parte do obiter dictum, mas também da ratio decidendi. Essa invocação, aliás, não aparece apenas nos votos individuais dos Ministros, mas também nas Ementas dos Acórdãos do Tribunal. No julgamento do famoso Habeas Corpus 82.424/Rio Grande do Sul, no qual o Tribunal entendeu, por maioria de votos, que a publicação de livro com conteúdo anti-semita caracterizaria crime de racismo, a invocação de legislação e jurisprudência constitucional estrangeira foi fundamental para a decisão, tanto que essa informação constou da Ementa do Acórdão:

9. Direito comparado. A exemplo do Brasil as legislações de países organizados sob a égide do estado moderno de direito democrático igualmente adotam em seu ordenamento legal punições para delitos que estimulem e propaguem segregação

50 BRASIL. Supremo Tribunal Federal. Ação Declaratória de Constitucionalidade 12 - Distrito Federal. Relator Min. Carlos Britto. Brasília, DF, 2008. Disponível em: http://redir.stf.jus.br/paginadorpub/ paginador.jsp? $\mathrm{doc} T \mathrm{TP}=\mathrm{AC} \& \operatorname{doc} \mathrm{ID}=606840$. Acesso em: 27 set. 2019.

51 BRASIL. Supremo Tribunal Federal. Arguição de Descumprimento de Preceito Fundamental 153 - Distrito Federal. Relator Min. Eros Grau. Brasília, DF, 2010. Disponível em: http://www.stf.jus.br/arquivo/ cms/noticianoticiastf/anexo/adpf153.pdf. Acesso em: 27 set. 2019. 52 O uso de teorias estrangeiras foi objeto de intenso debate no Supremo Tribunal Federal. A discussão veio à tona durante a conclusão do item sobre corrupção ativa na Ação Penal 470, o processo do Caso Mensalão. Vários ministros fizeram uso especialmente da Teoria do Domínio do Fato, desenvolvida pelo jurista alemão Claus Roxin. Dentre as várias teorias usadas, esta foi a que gerou intensa polêmica dentro e fora do tribunal, precisamente por ter constituído parte da ratio decidendi da decisão. Também recentemente, o uso da doutrina norte-americana foi marcante na jurisprudência da Corte. Confira-se, por exemplo, o julgamento da Arguição de Descumprimento de Preceito Fundamental (ADPF) 186, no qual o Supremo Tribunal Federal declarou constitucional a adoção do sistema de cotas para ingresso no ensino superior em instituições públicas. 
racial. Manifestação da Suprema Corte NorteAmericana, da Câmara dos Lordes da Inglaterra e da Corte de Apelação da Califórnia nos Estados Unidos que consagram entendimento [de] que [se] aplicam sanções àqueles que transgridem as regras de boa convivência social com grupos humanos que simbolizem a prática de racismo.

Em nossa pesquisa, foram analisados todos os Informativos de Jurisprudência produzidos pela própria Corte, acessíveis por meio de sua base online a partir da busca pela expressão direito comparado. Destacaram-se, por intermédio da utilização deste mecanismo, sem restrições a anos, relatores ou órgãos, 41 (quarenta e uma) referências ${ }^{53}$. Desses informativos são excluídos aqueles julgados que não dispunham ainda de acórdão ou decisão monocrática quanto ao seu mérito, assim como aquelas referências repetidas e julgados onde a menção constasse somente em voto-vista. Restaram assim 27 acórdãos ou decisões, de temas e relatorias diversas, sendo a mais antiga do ano de 2000, o RE 251445, Rel. Min. Celso de Mello (Informativo 197), e a mais recente o RE 638.491 Paraná, Rel. Min. Luiz Fux, julgado em 17 de maio de 2017 (Informativo 865) ${ }^{54}$.

Verificou-se, assim, que em significativa parcela das decisões - treze - a Corte se limitou a fazer referências genéricas ao direito comparado, tendo-se por referência genérica a menção à suposta posição estrangeira, com rápida indicação de um ou mais países, sem a devida atenção sequer à análise da jurisprudência ou da literatura, e com citações esporádicas. Nessas hipóteses, a utilização corresponde a verdadeiro uso de argumento de autoridade, já que não há análise real da situação jurídica da questão em direito comparado, limitando-se o julgado a invocar a experiência estrangeira como uma espécie de fonte de autenticidade ou de validação da posição.

Não se encontrou, nesses 13 (treze) casos, um movimento real no sentido da construção de argumento metodologicamente construído a título de pesquisa específica de Direito Constitucional Comparado, já que inexiste análise de identidade entre os casos, circunstâncias que os originaram, ou mesmo justificativa na escolha daquelas amostras. Sequer é possível descrever

\footnotetext{
53 Pesquisa realizada no site do STF (Disponível em: http:/ / www. stf.jus.br/portal/jurisprudencia/listarConsolidada.asp. Acesso em: 28 ago. 2019).

54 Informativos $923,865,849,841,779,771,738,732,722,719$, $711,710,697,663,661,658,657,656,650,632,631,614,584,554$, $549,467,466,419,417,376,371,351,343,310,259,198,197$ (referências 2, 26 e 36 em duplicidade e 41 um link vazio).
}

a natureza dessa análise. É forçoso concluir, em uma análise crítica, ainda que perfunctória, que as menções não agregam valor argumentativo à decisão, sendo, inclusive, dispensáveis ${ }^{55}$.

Em apenas 02 (dois) julgados, o STF foi um pouco mais longe (ADPF 54 - DF, Rel. Min. Marco Aurélio de Mello, julgada em 12 de abril de 2012 - Informativo 661 e Recurso Extraordinário - RE 638.491 - Paraná, Rel. Min. Luiz Fux, julgado em 2 de maio de 2013 - Informativo 865), apresentando-se um item específico na decisão para a análise da situação em Direito Comparado. Ainda assim, não há uma metodologia declarada, não se justifica a escolha dos países, não se explora as semelhanças e divergências entre o contexto jurídico de cada ordenamento, e não se analisa criticamente o momento histórico anterior e posterior à decisão.

Não há ainda qualquer análise consequencialista quanto aos resultados da mudança, seu sucesso ou insucesso, justificativas para a adesão a caminho semelhante, no máximo aduz-se a razoável semelhança entre a redação do texto constitucional naqueles países. Ou seja, novamente se encontra estudo insuficiente para configurar uma abordagem válida de Direito Constitucional Comparado, nos termos em que já exposto, e que, assim, possa atender a modelos críticos ou mesmo tradicionais. Apesar da maior dedicação ao estudo da matéria, a construção carece de metodologia.

Em um grupo um pouco menor de julgados, composto por 12 (doze) decisões, a Corte se limitou a citar julgados ou a mencionar a opinião da literatura de autores estrangeiros, de modo a demonstrar a semelhança daquelas posições com a adotada no julgamento em questão. Não há dados empíricos ou maiores análises, a indicação segue uma métrica mais breve e resumida que o grupo anterior.

Quanto à citação a ordenamentos jurídicos ou à literatura estrangeira como recursos em identificação da posição em direito comparado, ficaram na frente a Alemanha, com 10 (dez) decisões, e em seguida os Estados Unidos da América, com menção em 07 (sete) decisões, seguidos por Portugal, França, Espanha, Itália, Reino

\footnotetext{
55 Avaliação semelhante já fora realizada antes nesta Revista, sem, contudo, desenvolver-se pesquisa empírica como a aqui demonstrada, que pudesse apontar a extensão do fenômeno e suas sutilezas. HORBACH, Carlos Bastide. O direito comparado no STF: internacionalização da jurisdição constitucional brasileira. Revista de Direito Internacional. V.12, n.2, 2015.
} 
Unido e México. Há citações apenas esporádicas a outros países, como Argentina, Colômbia, Canadá, Cingapura, África do Sul, Austrália ou mesmo o Paquistão.

Conclui-se, assim, da análise empírica realizada, que se confirmou parcialmente a hipótese, uma vez que o Supremo Tribunal Federal não apresenta uma metodologia ou espécie de abordagem bem definida de utilização e aplicação de precedentes em Direito Constitucional Comparado. Utiliza, sem critérios científicos, e sem a incursão necessária, de decisões aleatórias - como auxílio às suas máximas argumentativas e argumento de autoridade pseudolegitimador de suas decisões, sem, todavia, amparar, mesmo esses precedentes, adequadamente na literatura jurídica do país de origem e no contexto político e histórico nacional de sua prolação.

Contudo, a Alemanha despontou como a nação mais citada, e apenas em seguida os Estados Unidos da América, o que aparenta ser motivado pela predileção em especial do Ministro Gilmar Mendes (Informativos $310,351,376,711$ ), grande utilizador das referências estrangeiras, e cuja formação fora parcialmente realizada naquele país, mas não só por ele, sendo referência frequente em votos do Ministro Luiz Fux (informativos $738,841$ e 865$)$.

\section{Considerações finais}

Inicialmente, partindo-se de questionamentos feitos pelo juiz Antonin Scalia, apontou-se que o crescente interesse pelo Direito Constitucional Comparado, por parte de juristas e cientistas sociais em geral, se deve, dentre outras coisas, à constatação da ocorrência de alguns fenômenos sociais e humanos comuns em âmbito global, cujos efeitos não se limitam à esfera jurídica. Esses fenômenos são relativamente recentes e, naturalmente, têm representado novos desafios ao desenvolvimento e estudo do direito constitucional. $\mathrm{O}$ entusiasmo por parte de acadêmicos de todos os continentes é evidenciado pela extraordinária quantidade de livros e artigos publicados nas últimas duas décadas.

Após a discussão sobre esta relevância, propôs-se uma sequência de etapas e requisitos metodológicos necessários para a construção de uma pesquisa em Direito Constitucional Comparado que não se confunda com mero argumento de autoridade ou a simples escolha aleatória de precedentes, de modo a apenas justificar a opinião do jurista. São traçadas assim três etapas e suas subdivisões, as quais pretendem, em síntese, abordar o que deve ser pesquisado, onde deve ser pesquisado quais fontes - e como realizar o cotejo dos dados, a dogmática e o problema de pesquisa apresentado.

Por fim, em um terceiro capítulo, alcançou-se a realidade do Supremo Tribunal Federal, apontando-se em meio a seus precedentes, metodologicamente selecionados, de que forma a Corte Suprema lida com o Direito Constitucional Comparado, em especial destacando-se a forma que a legislação estrangeira e os precedentes são apresentados, e a inexistência de uma metodologia adequadamente implantada, ou mesmo uniformidade quanto ao tratamento desses dados, o que resulta em diminuição do seu valor enquanto referencial decisório.

\section{Referências}

ACKERMAN, Bruce. The Rise of World Constitucionalism. Virginia Law Review, [S. 1.], v. 83, n. 4, p. 771-797, 1997.

BARroso, Luís Roberto. A Dignidade da Pessoa Humana no Direito Constitucional Contemporâneo: a Construção de um Conceito Jurídico à Luz da Jurisprudência Mundial. Belo Horizonte: Fórum, 2012.

BEATTY, David. A Essência do Estado de Direito. São Paulo: WMF Martins Fontes, 2014.

BRASIL. Supremo Tribunal Federal. Ação Declaratória de Constitucionalidade 29 - Distrito Federal. Relator Min. Luiz Fux. Brasília, DF, 2012. Disponível em: http://redir.stf.jus.br/paginadorpub/paginador. jsp?docTP=TP\&docID=2243342. Acesso em: 27 set. 2019.

BRASIL. Supremo Tribunal Federal. Ação Declaratória de Constitucionalidade 30 - Distrito Federal. Relator Min. Luiz Fux. Brasília, DF, 2012. Disponível em: http://redir.stf.jus.br/paginadorpub/paginador. jsp?docTP=TP\&docID=2243411. Acesso em: 27 set. 2019.

BRASIL. Supremo Tribunal Federal. Ação Declaratória de Constitucionalidade 12 - Distrito Federal. Relator Min. Carlos Britto. Brasília, DF, 2008. Disponível em: http://redir.stf.jus.br/paginadorpub/paginador. jsp?doc TP $=\mathrm{AC} \& \operatorname{docID}=606840$. Acesso em: 27 set. 2019. 
BRASIL. Supremo Tribunal Federal. Ação Direta de Inconstitucionalidade 3.510 - Distrito Federal. Relator Min. Ayres de Britto. Brasília, DF, 2008. Disponível em: http://redir.stf.jus.br/paginadorpub/paginador. jsp?docTP $=$ AC\&docID=611723. Acesso em: 27 set. 2019.

BRASIL. Supremo Tribunal Federal. Ação Direta de Inconstitucionalidade 3.367 - Distrito Federal. Relator Min. Cezar Peluso. Brasília, DF, 2005. Disponível em: https://stf. jusbrasil.com.br/jurisprudencia/765314/acao-diretade-inconstitucionalidade-adi-3367-df. Acesso em: 27 set. 2019.

BRASIL. Supremo Tribunal Federal. Ação Direta de Inconstitucionalidade 3.112-1 - Distrito Federal. Relator Min. Ricardo Lewandowski. Brasília, DF, 2007. Disponível em: http://www.stf.jus.br/imprensa/pdf/adi3112.pdf. Acesso em: 27 set. 2019.

BRASIL. Supremo Tribunal Federal. Ação Direta de Inconstitucionalidade 4.578 - Distrito Federal. Relator Min. Luiz Fux. Brasília, DF, 2012. Disponível em: http://redir.stf.jus.br/paginadorpub/paginador. jsp?docTP $=$ TP\&docID $=2257978$. Acesso em: 27 set. 2019.

BRASIL. Supremo Tribunal Federal. Arguição de Descumprimento de Preceito Fundamental 132 - Rio de Janeiro. Relator Min. Ayres Britto. Brasília, DF, 2011. Disponível em: http://redir.stf.jus.br/paginadorpub/paginador. jsp? docTP $=$ AC\&docID $=628633$. Acesso em: 27 set. 2019.

BRASIL. Supremo Tribunal Federal. Arguição de Descumprimento de Preceito Fundamental 54 - Distrito Federal. Relator Min. Marco Aurélio. Brasília, DF, 2012. Disponível em: http://redir.stf.jus.br/paginadorpub/paginador. jsp?docTP $=$ TP\&docID=3707334. Acesso em: 27 set. 2019.

BRASIL. Supremo Tribunal Federal. Arguição de Descumprimento de Preceito Fundamental 187 - Distrito Federal. Relator Min. Celso de Melo. Brasília, DF, 2011. Disponível em: http://www.stf.jus.br/arquivo/cms/noticiaNoticiaStf/anexo/ADPF187merito.pdf. Acesso em: 27 set. 2019.

BRASIL. Supremo Tribunal Federal. Arguição de Descumprimento de Preceito Fundamental 189 - São Paulo. Relator Min. Ricardo Lewandowski. Brasília, DF, 2012. Disponível em: https://stf.jusbrasil.com.br/jurisprudencia/21812440/arguicao-de-descumprimento-de- preceito-fundamental-adpf-189-sp-stf. Acesso em: 27 set. 2019.

BRASIL. Supremo Tribunal Federal. Arguição de Descumprimento de Preceito Fundamental 130 - Distrito Federal. Relator Min. Ayres Britto. Brasília, DF, 2009. Disponível em: http://redir.stf.jus.br/paginadorpub/paginador. jsp?docTP=AC\&docID=605411. Acesso em: 27 set. 2019.

BRASIL. Supremo Tribunal Federal. Arguição de Descumprimento de Preceito Fundamental 153 - Distrito Federal. Relator Min. Eros Grau. Brasília, DF, 2010. Disponível em: http://www.stf.jus.br/arquivo/cms/noticianoticiastf/ anexo/adpf153.pdf. Acesso em: 27 set. 2019.

BRASIL. Supremo Tribunal Federal. Habeas Corpus 82.424 - Rio Grande do Sul. Relator Min. Moreira Alves, redator para Acórdão Min. Maurício Corrêa. Brasília, DF, 2003. Disponível em: https://stf.jusbrasil.com. br/jurisprudencia/770347/habeas-corpus-hc-82424-rs. Acesso em: 27 set. 2019.

BRASIL. Supremo Tribunal Federal. Habeas Corpus 82.959-7 - São Paulo. Relator Min. Marco Aurélio. Brasília, DF, 2006. Disponível em: http://www.stf. jus.br/noticias/imprensa/VotoGilmarHC82959.pdf. Acesso em: 27 set. 2019.

BRASIL. Supremo Tribunal Federal. Habeas Corpus 91.952-9 - São Paulo. Relator Min. Marco Aurélio. Brasília, DF, 2008. Súmula Vinculante no 11. Disponível em: http://redir.stf.jus.br/paginadorpub/paginador. jsp?docTP $=$ AC\&docID=570157. Acesso em: 27 set. 2019.

BRASIL. Supremo Tribunal Federal. Mandado de Injunção 670 - Espirito Santo. Relator Min. Gilmar Mendes. Brasília, DF, 2007. Disponível em: https:/ /stf.jusbrasil. com.br/jurisprudencia/2926661/mandado-de-injuncao-mi-670-es. Acesso em: 27 set. 2019.

BRASIL. Supremo Tribunal Federal. Mandado de Injunção 708 - Distrito Federal. Relator Min. Gilmar Mendes. Brasília, DF, 2007. Disponível em: https:/ /stf.jusbrasil. com.br/jurisprudencia/14725991/mandado-de-injuncao-mi-708-df. Acesso em: 27 set. 2019.

BRASIL. Supremo Tribunal Federal. Mandado de Injunção 712-8 - Pará. Relator Min. Eros Grau. Brasília, DF, 2007. Disponível em: http://www.stf.jus.br/imprensa/ PDF/mi712.pdf. Acesso em: 27 set. 2019. 
BRASIL. Supremo Tribunal Federal. Mandado de Segurança 24.831-9 - Distrito Federal. Relator Min. Celso de Mello. Brasília, DF, 2005. Disponível em: http:// www2.stf.jus.br/portalStfInternacional/cms/verConteudo.php?sigla $=$ portalStfJurisprudencia_pt_ br\&idConteudo $=185070 \&$ modo $=\mathrm{cms}$. Acesso em: 27 set. 2019.

BRASIL. Supremo Tribunal Federal. Mandado de Segurança 26.602 - Distrito Federal. Relator Min. Eros Grau. Brasília, DF, 2007. Disponível em: https:/ /www.jusbrasil.com.br/topicos/27706686/stf-mandado-de-seguranca-ms-26602-df. Acesso em: 27 set. 2019.

BRASIL. Supremo Tribunal Federal. Petição 3.388 Roraima. Relator Min. Ayres Britto. Brasília, DF, 2009. Disponível em: http://redir.stf.jus.br/paginadorpub/ paginador.jsp?doc $\mathrm{TP}=\mathrm{TP} \& \operatorname{doc} \mathrm{ID}=5214423 . \quad$ Acesso em: 27 set. 2019.

BRASIL. Supremo Tribunal Federal. Recurso Extraordinário 201.819-8 - Rio de Janeiro. Relatora Min. Ellen Gracie. Brasília, DF, 2005. Disponível em: http: / / redir.stf.jus.br/paginadorpub/paginador. jsp?docTP $=$ AC\&docID=388784. Acesso em: 27 set. 2019.

BRASIL. Supremo Tribunal Federal. Recurso Extraordinário 349.703 - Rio Grande do Sul. Relator Min. Carlos Britto. Brasília, DF, 2008. Disponível em: http:// redir.stf.jus.br/paginadorpub/paginador. jsp?docTP $=$ AC\&docID=595406. Acesso em: 27 set. 2019.

BRASIL. Supremo Tribunal Federal. Recurso Extraordinário 466.343-1 - São Paulo. Relator Min. Cezar Peluso. Brasília, DF, 2008. Disponível em: http: / / redir.stf.jus.br/paginadorpub/paginador. jsp?docTP $=$ AC\&docID=595444. Acesso em: 27 set. 2019.

CHANG, Wen-Chen; YEH, Jiunn-Rong. The Emergence of Transnational Constitutionalism: Its Features, Challenges and Solutions. Penn State International Law Review, Carlisle, v. 27, n. 1, p. 89-124, 2009.

CHOUDHRY, Sujit. The Migration of Constitutional Ideas. New York: Cambridge University Press, 2006.

CRUZ, Peter de. Comparative Law in a Changing World. 2nd edn. London: Routledge Cavendish, 1999. p. 233239.

DANNEMANN, Gerhard. Comparative Law: Study of
Similarities or Differences? In: REIMANN, Mathias; ZIMMERMANN, Reinhard (eds.). The Oxford Handbook of Comparative Law. Oxford: Oxford University Press, 2006.

DUTRA, Deo Campos. Métodos em Direito Comparado. Revista da Faculdade de Direito - UFPR, Curitiba, v. 61, n. 3, p. 189-212, set./dez. 2016.

ERSKINE, Daniel H. Judgments of the United States Supreme Court and the South African Constitutional Court as a Basis for a Universal Method to Resolve Conflicts Between Fundamental Rights. St. John's Journal of Legal Commentary, [S. 1.], v. 22, n. 3, p. 595-641, 2008.

EWALD, William. Comparative Jurisprudence (I): What Was It Like to Try a Rat? University of Pennsylvania Law Review, v. 143, n. 6, p. 1889-2149, 1995. p. 1990 e ss.

EWALD, William. The Jurisprudential Approach to Comparative Law: A Field Guide to "Rats". American Journal of Comparative Law, Oxford, v. 46, n. 4, p. 701707, 1998.

FREIRE, Alonso. Interpretação constitucional comparativa: aproximação crítica e arcabouço metodológico. Publicum, Rio de Janeiro, v. 2, n.1, 2016. Disponível em: http://www.e-publicacoes.uerj.br/. Acesso em: 20 jun. 2017.

FREIRE, Alonso. O Supremo Tribunal Federal e a Migração de Ideias Constitucionais: Considerações sobre a Análise Comparativa na Interpretação dos Direitos Fundamentais. In: CLÈVE, Clèmerson Merlin; FREIRE, Alexandre (eds.). Direitos Fundamentais e Jurisdição Constitucional: Análise, Crítica e Contribuições. São Paulo: Revista dos Tribunais, 2014. p. 50-75.

GARTH, Bryan G. The Globalization of Law. In: WHITTINGTON, Keith; KELEMEN, R. Daniel; CALDEIRA, Gregory A. The Oxford Handbook of Law and Politics. New York: Oxford University Press, 2008. p. 245-264.

GELTER, Martin; SIEMS, Mathias. Citations to Foreign Courts - Illegitimate and Superfluos, or Unavoidable? Evidence from Europe. The American Journal of Comparative Law, Oxford, v. 62, n. 35, p. 35-86, 2014.

GINSBURG, Tom. Comparative Constitutional Design. New York: Cambridge University Press, 2012.

GINSBURG, Tom. Judicial Review in New Democracies: Constitutional Cases in Asian Cases. New York: Cambridge University Press, 2003. 
GINSBURG, Tom; DIXON, Rosalind. Introduction. In: GINSBURG, Tom; DIXON, Rosalind (eds.). Comparative Constitutional Law. Cheltenham: Edward Elgar, 2011.

GLENN, H. Patrick. Comparative Legal Families and Comparative Legal Traditions. In: REIMANN, Mathias; ZIMMERMANN, Reinhard (eds.). The Oxford Handbook of Comparative Law. Oxford: Oxford University Press, 2006. p. 421-440.

GLENN, H. Patrick. Legal Traditions of the World: Sustainable Diversity in Law. Oxford: Oxford University Press, 2014.

GRAZIADEI, Michele. Comparative Law as the Study of Transplants and Receptions. In: REIMAN, Mathias; ZIMMERMANN, Reinhard (eds.). The Oxford Handbook of Comparative Law. Oxford: Oxford University Press, 2006. p. 441-512.

GRAZIADEI, Michele. Legal Transplants and the Frontiers of Legal Knowledge. Theoretical Inquiries in Law, [S. 1.], v. 10, n. 2, p. 723-743, 2009.

GRIFFITHS, John. What is Legal Pluralism? Journal of Legal Pluralism and Unofficial Law, n. 24, p. 1-55, 1986.

GROPPI, Tania; PONTHOREAU, Marie-Claire. The Use of Foreign Precedents by Constitutional Judges. Oxford: Hart Publishing, 2014.

HALMAI, Gábor. The Use of Foreign Law in Constitutional Interpretation. In: ROSENFELD, Michel; SAJÓ, András (eds.). The Oxford Handbook of Constitutional Law. Oxford: Oxford University Press, 2012. p. 1328-1348.

HILBINK, Lisa. Judges Beyond Politics in Democracy and Dictatorship: Lessons from Chile. New York: Cambridge University Press, 2007.

HIRSCHL, Ran. Comparative Matters: The Renasissance of Comparative Constitutional Law. Oxford: Oxford University Press, 2014.

HIRSCHL, Ran. The Rise of Comparative Constitutional Law: Thoughts on Substance and Method. Indiana Journal of Constitutional Law, [S. 1.], v. 1, n. 2, p. 11-37, 2008.

HIRSCHL, Ran. Towards Juristocracy: The Origins and Consequences of the New Constitutionalism. Cambridge: Harvard University Press, 2004.

HOECKE, Mark Van. Deep Level Comparative Law. In: HOECKE, Mark Van (ed.). Epistemology and Methodo- logy of Comparative Law. Oxford: Hart, 2004. p. 165-195. HOECKE, Mark Van; WARRIGNTON, Mark. Legal Cultures, Legal Paradigmas and Legal Doctrine: Towards a New Model of Comparative Law. International and Comparative Law Quarterly, Cambrigdge, v. 47, n. 3, p.495-536, 1998.

HORWITZ, Morton J. Constitutional Transplants. Theoretical Inquiries in Law, [s. 1.], v. 10, n. 2, p. 535-560, 2009.

JACKSON, Vicki C. Comparative Constitutional Law: Methodologies. In: ROSENFELD, Michel; SAJÓ, András (eds.). The Oxford Handbook of Constitutional Comparative Law. Oxford: Oxford University Press, 2012.

JACKSON, Vicki C. Constitutional Engagement in a Transnational Era. New York: Oxford University Press, 2010.

JANSEN, Nils. Comparative Law and Comparative Knowledge. In: REIMANN, Mathias; ZIMMERMANN, Reinhard (eds.). The Oxford Handbook of Comparative Law. Oxford: Oxford University Press, 2006. p. 320-325.

KENDE, Mark S. Constitutional Rights in Two Worlds: South Africa and the States. New York: Cambridge University Press, 2009.

KOMÁREK, Jan. Reasoning with Previous Decisions. In: ADAMS, Maurice. (ed.). Practice and Theory in Comparative Law. Cambridge: Cambridge University Press, 2012. p. 49-73.

LAW, David S. Globalization and the Future of Constitutional Rights. Northwestern University Law Review, [S. 1.], v. 102, n. 3, p. 1.277-1.350, 2008.

LAW, David S; VERSTEEG, Mila. The Evolution and Ideology of Global Constitutionalism. California Law Review, [S. 1.], v. 99, n. 5, p. 1163-1257, 2011.

MALDONADO, Danile Bonilla. Constitutionalism of Global South: The Activist Tribunals of India, South Africa and Colombia. New York: Cambridge University Press, 2013.

MENSKI, Werner. Comparative Law in Global Context. Cambridge: Cambridge University Press, 2006. p. 82 e ss.

MEUWESE, Anne; VERSTEEG, Mila. Quantitative Methods for Comparative Constitutional Law. In: ADAMS, Maurice; BOMHOFF, Jacco (eds.). Practice and Theory in Comparative Law. Cambridge: Cambridge University Press, 2012. p. 230-257. 
MICHAELS, Ralf. The Functional Method of Comparative Law. In: REIMANN, Mathias; ZIMMERMANN, Reinhard (eds.), The Oxford Handbook of Comparative Law. Oxford: Oxford University Press, 2006. p. 342.

NEVES, Marcelo. Transconstitucionalismo. São Paulo: WMF Martins Fontes, 2009.

ÖRÜCÜ, Esin. Methodological Aspects of Comparative Law. European Journal of Law Reform, [S. 1.], v. 8, p. 2942, 2006; SIEMS, Mathias. Comparative Law. Cambridge: Cambridge University Press, 2014.

ÖRÜCÜ, Esin. The Enigma of Comparative Law: Variations on a Theme for Twenty-First Century. Leiden: Martius Nijhoff, 2004.

PERJU, Vlad. Constitutional Transplants, Borrowing, and Migrations. In: ROSENFELD, Michel; SAJÓ, András (eds.). The Oxford Handbook of Comparative Constitutional Law. Oxford: Oxford University Press, 2012.

REYNOLDS, Andrew. The Architecture of Democracy: Constitutional Design, Conflict Management, and Democracy. New York: Oxford University Press, 2002.

ROSENFELD, Michel. The Rule of Law and the Legitimacy of Constitutional Democracy. Southern California Law Review, [S. 1.], v. 74, p. 1307-1352, 2001.

ROSENFELD, Michel; SAJÓ, András. Introduction. In: ROSENFELD, Michel; SAJÓ, András (eds.). The Oxford Handbook of Constitutional Law. Oxford: Oxford University Press, 2012. p. 3.

ROUX, Theunis. The Politcs of Principle: The First South African Constitutional Court, 1995-2005. Cambridge: Cambridge University Press, 2013.

SADURSKI, Wojciech. Rights Before Courts: A Study of Constitutional Courts in Postcommunist States of Central and Eastern Europe. 2nd. New York: Springer, 2014.

SAMUEL, Geoffrey. Comparative Law and Jurisprudence. International and Comparative Law Quarterly, Cambrigdge, v. 47, n. 4, p. 817-836, 1998.

SARMENTO, Daniel; SOUZA NETO, Cláudio Pereira de. Direito Constitucional: Teoria, História e Métodos de Trabalho. Belo Horizonte: Fórum, 2012.

SCALIA, Antonin. Keynote address: Foreign Legal Authority in the Federal Courts. Proceedings to the Annual Meeting, Cambridge, v. 98, march/april, p. 305-310, 2004.

SIEMS, Mathias. Comparative Law. Cambridge: Cam- bridge University Press, 2014.

SLAUghter, Anne-Marie. A New World Order. New Jersey: Princeton University Press, 2004.

SPIRO, Peter J. Globalization and the (Foreign Affairs) Constitution. Obio State Law Journal, [S. 1.], v. 63, n. 2, p. 649-730, 2002.

SWEET, Alec Stone; MATHEWS, Jud. Proportionality Balancing and Global Constitutionalism. Columbia Journal of Transnational Law, New York, v. 47, p. 68-149, 2008.

TROCHEV, Alexei. Judging Russia: The Role of Constitutional Court in Russian Politics 1990-2006. New York: Cambridge University Press, 2008.

TUSHNET, Mark V. Alternative Forms of Judicial Review. Michigan Law Review, v. 101, n.8, p. 2781-2802, 2003.

TUSHNET, Mark V. Comparative Constitutional Law. In: REIMANN, Mathias; ZIMMERMANN, Reinhard (eds.). The Oxford Handbook of Comparative Law. Oxford: Oxford University Press, 2006. p. 1226.

TUSHNET, Mark. The Possibilities of Comparative Constitutional Law. Yale Law Journal, v. 108, n. 6, p. 1229-1230, 1999.

TUSHNET, Mark. Weak Courts, Strong Rights: Judicial Review and Social Welfare Rights in Comparative Constitutional Law. New Jersey: Princeton University Press, 2008.

UNGER, Roberto Mangabeira. A constituição do experimentalismo democrático. Revista de Direito Administrativo, Rio de Janeiro, v. 257, p. 57-72, maio-ago. 2011.

UNITED STATES. SUPREME COURT OF THE UNITED STATES. Olympic Airways v. Husain, 540 U.S. 644 (2004). Disponível em: https://supreme.justia. com/cases/federal/us/540/644/. Acesso em: 27 set. 2019.

UNITED STATES. THE UNITED STATES COURT OF APPEALS FOR THE NINTH CIRCUIT. Sosa v. Alvarez-Machain, 542 U.S. 692. 2004. Disponível em: http://cdn.loc.gov/service/ll/usrep/usrep542/ usrep542692/usrep542692.pdf. Acesso em: 28 ag. 2019.

VALCKE, Catherine. Comparative Law as Comparative Jurisprudence: The Comparability of Legal Systems. American Journal of Comparative Law, Oxford, n. 52, p. 713-740, 2004. 
WALDRON, Jeremy. Partly laws common to all mankind: foreign law in american courts. New Haven: Yale University Press, 2012. p. 103.

WHITMAN, James Q. The Neo-Romantic Turn. In: LEGRAND, Pierre; MUNDAY, Roderick (eds.). Comparative Legal Studies: Traditions and Transitions. Cambridge: Cambridge University Press, 2003. p. 313.

WHYTOCK, Christopher A. Legal Origins, Functionalism, and the Future of Comparative Law. Brigham Young University Law Review, [S. 1.], n. 6, p. 1879-196, 2009. p. 1881.

WHYTOCK, Christopher A. Legal Origins, Functionalism, and the Future of Comparative Law, p. 1876 e ss; SIEMS, Mathias. Comparative Law. Cambridge: Cambridge University Press, 2014. p. 28-29.

WILSON, Bruce M. Constitutional Rights in the Age of Assertive Superior Courts: An Evalutation of Costa Rica's Constitutional Chamber of the Supreme Court. Willamette Law Review, [S. 1.], v. 48, n. 4, p.451-471, 2012.

ZWEIGERT, Konrad; KÖTZ, Hein. An Introduction to Comparative Law. 3 rd. Oxford: Clarendon, 1998.

ZWEIGERT, Konrad; KÖTZ, Hein. An Introduction to Comparative Law. 3rd. Oxford: Clarendon, 1998. p. 79. 
Para publicar na Revista de Direito Internacional, acesse o endereço eletrônico www.rdi.uniceub.br ou www.brazilianjournal.org.

Observe as normas de publicação, para facilitar e agilizar o trabalho de edição. 